\title{
Water Budget Analysis of Agulu Lake in Anambra State, Nigeria \\ ${ }^{1}$ EGBOKA, BCE; ${ }^{2}$ NFOR, BN; ${ }^{3}$ BANLANJO, EW
}

\author{
${ }^{1,3}$ Department of Geological Sciences, Nnamdi Azikiwe University, Nigeria
}

${ }^{2}$ Dept of Geology, Delta State University, Abraka, Nigeria

\begin{abstract}
The elements of water budget equation were analyzed for the Agulu lake area and underlying aquifers. The water budget implications for soil and gully erosion were evaluated in relation to the geological formations and hydrogeotechnics. Results show that rainfall constitutes the main source of precipitation. It ranges from $1714.04 \mathrm{~mm}$ to $1995.53 \mathrm{~mm}$ annually. The potential groundwater aquifer volume is $1.5 \times 10^{7} \mathrm{~m}^{3}$. Discharge from aquifers contributes $7.4 \times 10^{7} \mathrm{~m}^{3}$ water annually. The amount of $1.72 \times 10^{5} \mathrm{~m}^{3}$ that is $60 \%$ of precipitation is lost to evaporation; 17 to $21 \%$ to infiltration. The quasi steady state of the lake water level and volume shows surface and groundwater continuity as explained by the small difference between total input and output values of the computed water budget of the lake and the aquifer. Flood studies indicate that $19.5 \%$ of the annual precipitation constitutes runoff, the main agent of gully and soil erosion, flooding and landslides. The other factors that control the distribution and location of gullies are lithologic and stratigraphical, while topography/geomorphology controls gully distribution within various geologic units. A typical gully is about $500 \mathrm{~m} \mathrm{X} \mathrm{50m} \mathrm{X} 30 \mathrm{~m}$ long, wide and deep respectively. The destruction to life and property by runoffs/floods demands joint and sustained efforts by the community dwellers, NGOs, Local Government Areas, State governments, Federal Government and the International Communities. (a)JASEM
\end{abstract}

Agulu Lake lies within the Anambra Basin, where monstrous effects of flood, soil and gully erosion and landslides destroy lives and property. Soil/gully erosion and landslides within the basin are associated with weak, poorly consolidated sandy lithologic units of Nanka Sands, Ameki Formation, Ogwashi-Asaba Formation, the coastal plain sands and their weathered products. Gully vertical profiles consist of relatively uniform reddish brown non-indurated lateritic sandy soils and whitish unconsolidated sands in deeper zones. Thin bands of clay and feruginized materials occasionally occur. The study shows that gullies are mostly initiated by anthropogenic activities such as footpaths, cattle tracks, roadside drains and exacerbated by infrastructural development. The rate of growth of gullies ranges from $10 \mathrm{~m}-50 \mathrm{~m}$ annually. The growth is slowest in the dry season. This brings to focus the contributory effects of water in gully erosion studies and hence, the importance of water budget analysis in flood and gully erosion studies and control in Agulu-lake and its environs. The objectives of the present study are to investigate and carry out water budget analysis of Agulu Lake areas and the underlying aquifers and relate these to the gully erosion problems.

\section{MATERIALS AND METHODS}

Field and desk studies were used. Field studies involved identification of major erosion sites, gully dimension measurements, discussions with affected community dwellers. Physiographic studies, hydrometeorological data were collected from Enugu Airport and the Ministry of Agriculture, Awka.
Drainage measurement were taken and quantitative definitions of the water input and output done by dividing the study area into geologic blocks viz; Nanka, Imo. Nsugbe and Ogwashi-Asaba Formations. Aquifer hydraulics and parameters were computed. Rainfall, temperature, relative humidity, wind speed and sunshine data for ten years (19871997) were used. Data on the destructive events of floods, soil and gully erosion and landslides that are endemic in Agulu Lake area were collected. The water budget and erosion data are correlated to understand the ecological problems in the area.

Geology Of The Anambra Basin: The study area lies within latitudes $5^{0} 15^{\prime}-5^{0} 55^{\prime} \mathrm{N}$ and longitudes $7^{0} 15^{\prime}-$ $6^{0} 55^{\prime} \mathrm{E}$, in the Anambra Basin. (Fig. 1). Subsistence of the Anambra plate due to folding and uplift of the Abakaliki-Benue fold belt in the Santonian stage produces the Anambra Basin. The basin is dominantly filled with clastic sediments constituting several distinct lithostratigraphic units deposited from Upper Campanian to Recent. The lithostratigraphic units have a thickness of up to $2,500 \mathrm{~m}$. These include; Nkporo Shale, mamu Formation, Ajali Sandstone, Nsukka Formation, Imo Shale, Nanka/Ameki, Sands/Formation, Nsugbe Formation and Ogwashi-Asaba Formations. The sediments were derived from the uplands beyond the Benue Hinge Line, the Abakaliki Uplands and the Benue fold belt. The youngest sediments are loose and exceptionally prone to erosion. Sampling was carried out from representative geologic formations as shown in figure 2 . 


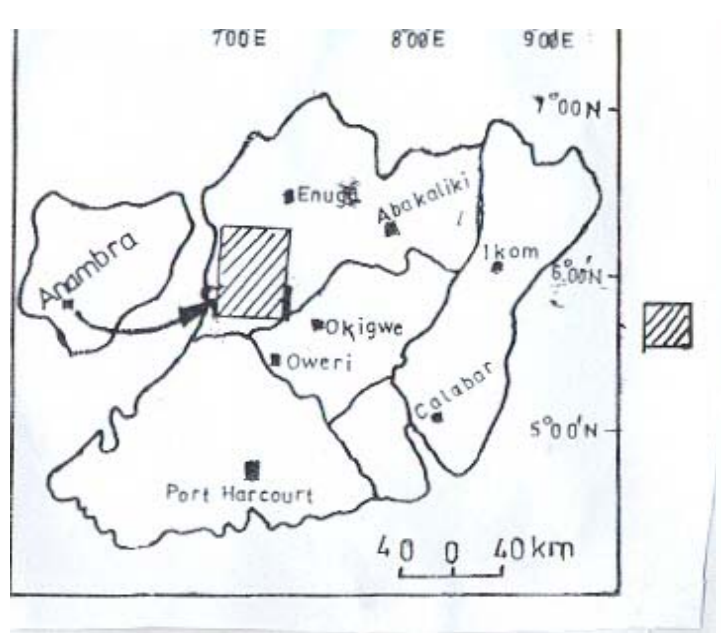

Fig. 1 Location map of the study area

Mathematical Analysis Of Water Budget And The Results:Water budget is an application of the principle of conservation of mass expressed as measurement of continuity of water flow in a continuity equation. The general water budget is defined as:

$$
\text { Input }- \text { Output }- \text { Increase in Storage }=0
$$

Output elements include groundwater recharge (GWR), evapotranspiration (ET), interception loss (IL), depression storage (DS), and runoff (R). Inputs (I) into the hydrologic system are from groundwater discharge and/or precipitation, which is principally rainfall. The average annual rainfall over the area is $1,854.79 \mathrm{~mm}$. Potential evapotranspiration (PET) was calculated using Penmann's Formula (1948) and

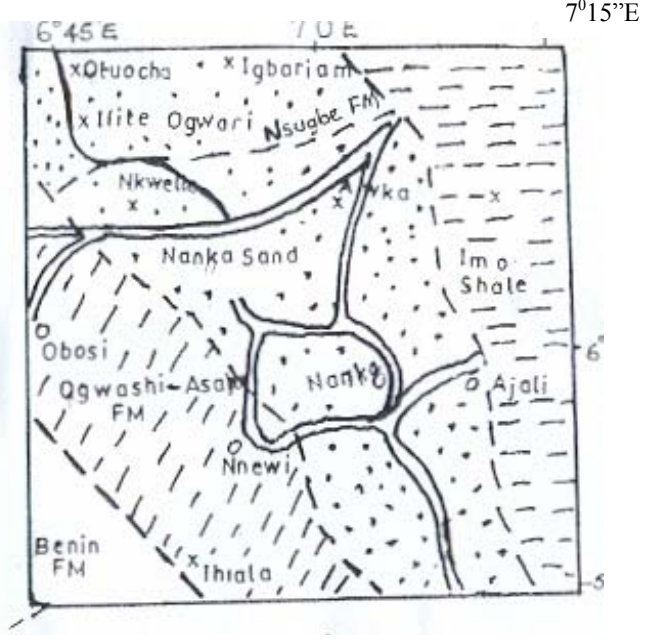

Fig. 2: Hydrometeorological and sampling locations within each geologic formation (FM) in the study area. (Adapted from Egboka and Okpoko, 1984)

corrected to actual value (AET) using the hydrologic aridity index and the results are presented in Table 1 . The Penmann's Formula is expressed mathematically as;

Where;

$$
\mathrm{PET}=\mathrm{Ahn}+\mathrm{EaY} / \mathrm{A}+\mathrm{Y} \ldots . .(2)
$$

$\mathrm{PET}=$ daily potential evaporation in $\mathrm{mm} /$ day; $\mathrm{A}=$ slope of saturation vapour pressure Vs temperature curve at mean air; temperature in $\mathrm{mmHg} /{ }^{0} \mathrm{C} ; \mathrm{Hn}=$ net radiation $(\mathrm{mm})$ of evaporatable water per day; $\mathrm{Y}=$ psychometric constant $\left(0.49 \mathrm{mmHg} /{ }^{0} \mathrm{C}\right) ; \mathrm{Ea}=$ parameter including wind velocity and saturation deficit

Table 1: Average PET And AET Values For Various Formations In The Study Area

\begin{tabular}{|l|c|c|c|c|c|}
\hline & \multicolumn{2}{|c|}{ PET } & \multicolumn{3}{c|}{ AET* } \\
\hline Formation & $\mathrm{mm} /$ day & $\mathrm{mm} /$ year & $\mathrm{mm} /$ day & $\mathrm{mm} /$ year & Precipitation (\%) \\
\hline Nanka & 4.68 & 1708.20 & 3.042 & 1110.33 & 63.4 \\
\hline Imo & 4.91 & 1792.15 & 3.192 & 1164.90 & 65.0 \\
\hline Nsugbe & 4.79 & 1748.35 & 3.114 & 1136.43 & 66.3 \\
\hline Ogwashi-Asaba & 4.40 & 1606.00 & 2.860 & 1043.90 & 52.3 \\
\hline
\end{tabular}

The correcting factor used for AET is 0.35 . Results show that A.E.T of the Agulu Lake area ranges from $1018.2 \mathrm{~mm} / \mathrm{yr}$. in Ogwashi-Asaba Formation to as high as $1095.5 \mathrm{~mm} / \mathrm{yr}$. in the Nsugbe
Formation. Wide range of precipitation values corresponds to wide temperature ranges $\left(33^{\circ} \mathrm{C}\right.$ to $27^{\circ} \mathrm{C}$ ) as well as the variation of vegetation: from densely vegetated areas underlain by the Imo Shale to the sparse vegetation in the Ogwashi-Asaba 
Water Budget Analysis of Agulu Lake...

Formation outcrops. The agricultural Aridity index or anomaly and the severity measure of hydrologic aridity index (AI), a percentage measure of drought is given in Table 2

Table 2: Aridity Index Measure And Its Description_(Subramanya, 1994)

\begin{tabular}{cccc}
\hline Aridity Anomaly & Severity class & Hydrologic Aridity Index & Description \\
\hline $1-25$ & Mild arid & 0.03 & Hyper-arid \\
$26-50$ & Moderate arid & $0.03-0.02$ & Arid \\
Greater than 50 & Severe arid & $0.02-0.50$ & Semi-arid \\
& & $0.50-0.75$ & Sub-humid
\end{tabular}

Infiltration in different lithologies was calculated using the formula;

$$
\mathrm{R}=\alpha(\mathrm{P}-\mathrm{Po})^{\mathrm{B}}
$$

Where; $\mathrm{R}=$ infiltration (groundwater recharge); $\alpha=$ coefficient, depending on soil types $(0.2$ for all formations 0.192 for lake; recharge); $\mathrm{Po}=$ infiltration index $(0.10 \mathrm{~cm} / \mathrm{hr}$.) at maximum flood, for design purposes. $\mathrm{B}=$ value approximately.

Infiltration results, presented in Table 3 show that loose/permeable soils have high values unlike the layered impermeable shales/clays. Even the fractured shales failed impart an expected infiltration increase.

Table 3: Average Groundwater Recharge In The Study Area

\begin{tabular}{lccc}
\hline Formation & $\begin{array}{l}\text { Precipitation } \\
(\mathrm{mm} / \mathrm{yr} .)\end{array}$ & $\begin{array}{l}\text { Groundwater } \\
\text { recharge } \\
(\mathrm{mm} / \mathrm{yr} .)\end{array}$ & $\begin{array}{l}\text { Precipitation } \\
(\%)\end{array}$ \\
\hline Nanka & 1751.23 & 367.55 & 21.4 \\
Imo & 1793.95 & 305.00 & 17.00 \\
Nsugbe & 1714.03 & 359.74 & 20.99 \\
Ogwashi-Asaba & 1995.93 & 418.94 & 20.99 \\
\hline
\end{tabular}

Runoff values were computed using Barlow's coefficient/equation expressed mathematically as;

$$
\mathrm{R}=\mathrm{K}_{\mathrm{b}} \mathrm{P}
$$

Where, $\mathrm{K}_{\mathrm{b}}=$ runoff coefficient, $\mathrm{P}=$ precipitation, $\mathrm{R}=$ runoff.
Computed results (presented in Table 4), show that the highest percentage of runoff $(26 \%$ of the average annual precipitation) occurs in areas where the Ogwashi-Asaba Formation outcrops. This could be associated with sparse vegetation and average annual temperatures $\left(29.66^{\circ} \mathrm{C}\right)$.

Table 4: Average Yearly Runoff In The Study Area

\begin{tabular}{lccc}
\hline Formation & $\begin{array}{l}\text { Precipitation } \\
(\mathrm{mm} / \mathrm{yr} .)\end{array}$ & $\begin{array}{l}\text { Runoff } \\
(\mathrm{mm} / \mathrm{yr} .)\end{array}$ & $\begin{array}{l}\text { Precipitation } \\
(\%)\end{array}$ \\
\hline Nanka & 1751.23 & 273.35 & 15.60 \\
Imo & 1793.95 & 324.05 & 18.06 \\
Nsugbe & 1714.03 & 217.86 & 12.70 \\
Ogwashi- & 1995.93 & 533.09 & 26.00 \\
Asaba & & & \\
\hline
\end{tabular}

Aquifer Groundwater Volume: The Nanka Sand (the main aquifer of the Agulu Lake hydrological system), measures $5000 \mathrm{~m} \times 100 \mathrm{~m} \times 30 \mathrm{~m}$ (Ogbukagu, $1988)$, giving an aquifer potential of $1.5 \times 10^{7} \mathrm{~m}^{3}$. An annual average precipitation of $1,751.23 \mathrm{~mm}$ represents an input volume of $8.755 \times 10^{5} \mathrm{~m}^{3}$ into the lake. Ogbukagu, (1988) also shows that the average annual groundwater discharge from bordering aquifers into the lake is $7.4 \times 10^{7} \mathrm{~m}^{3} / \mathrm{yr}$. The distribution of these results for the input and output values within each geologic formation is summarized as a general water budget (shown in Table $5)$. 
Table 5: General Ground Water Budget For The Hydrologic System

$\mathrm{P}=$ Precipitation; $\mathrm{E}=$ Evapotranspiration; $\mathrm{GWR}=$ Groundwater Recharge;

\begin{tabular}{|c|c|c|c|c|}
\hline Formation & $\mathrm{P}(\mathrm{mm} / \mathrm{yr})$. & $\mathrm{E}(\mathrm{mm} / \mathrm{yr})$. & GWR $(\mathrm{mm} / \mathrm{yr})$. & $\mathrm{R}(\mathrm{mm} / \mathrm{yr})$ \\
\hline Nanka & 1751.23 & 1072.14 & 367.55 & 311.54 \\
& $* 5.762 \times 10^{8}$ & $* 3.527 \times 10^{8}$ & $* 1.209 \times 10^{8}$ & $* 1.025 \times 10^{8}$ \\
\hline Imo & 1793.95 & 1199.4 & 305.00 & 289.55 \\
& $* 5.992 \times 10^{8}$ & $* 4.005 \times 10^{8}$ & $* 1.019 \times 10^{8}$ & $* 9.671 \times 10^{7}$ \\
\hline Nsugbe & 1714.03 & 1095.5 & 359.74 & 258.79 \\
& $* 5.312 \times 10^{8}$ & $* 3.396 \times 10^{8}$ & $* 1.115 \times 10^{8}$ & $* 8.023 \times 10^{7}$ \\
\hline Ogwashi-Asaba & 1751.23 & 1018.2 & 418.94 & 558.79 \\
& $* 5.762 \times 10^{8}$ & $* 9.57 \times 10^{7}$ & $* 3.938 \times 10^{7}$ & $* 5.253 \times 10^{7}$ \\
\hline General budget & 1995.93 & 1096.31 & 362.801 & 354.668 \\
& $* 1.94 \times 10^{9}$ & $* 1.17 \times 10^{9}$ & $* 3.87 \times 10^{8}$ & $* 3.784 \times 10^{8}$ \\
\hline
\end{tabular}

$R=$ runoff; $*=$ Volumes $\left(M^{3}\right) ; A$ summary of the summation of the input and output elements of the water budget equation from the various formations of the hydrologic system is given as follows; (a) Groundwater discharge $=7.4 \times 10^{7} \mathrm{~m}^{3}$. Precipitation $=7.9 \times 10^{5} \mathrm{~m}^{3}$ Groundwater recharge $=1.72 \times 10^{5} \mathrm{~m}^{3} ;$ Evapotranspiration $=5.29 \times 10^{5} \mathrm{~m}^{3}$ Volume of water maintained throughout the year $=1.5 \times 10^{7} \mathrm{~m}^{3}$ (f) Runoff $=5.91 \times 10^{7} \mathrm{~m}^{3}$

Implications Of Analysed Water Budget In Gully Erosion Studies/Design: Overflow (Runoff) flows over the soil surface as concentrates in micro drainage patterns. The later merge to form rills, gullies or streams that provide drainage paths for runoff water. Flood studies shows that only $19.5 \%$ of the annual precipitation constitutes runoff (Table 5). Yet runoff constitutes main agent of gully and soil erosion, flooding and landslides. The high energy possessed by runoffs is expended on obstacles along its path- loosening and picking them up. Overflows are mostly devastating in August, September and October (flood months, water being slightly subject to evaporation). Infiltration controls runoffs, soil moisture content, and the binding forces between grains and hence influences slumping in existing gullies. The other effects of infiltration include; dissolving minerals from soils, reducing capillary tension that binds soils together, increasing bulk density of materials and hence altering intra-mass stresses. It induces hydraulic pressure and hence stresses the particles resulting in "quick-conditions". It causes seepages, internal erosion and reduces the support offered by soil layers to the overlying materials and hence slumping and sliding. Rainfall. The gullying effects of raindrops (of diameter $6 \mathrm{~mm}$ and velocity $305 \mathrm{~mm} / \mathrm{sec}$ common in the study area) as they strike the soil with intense velocity are summarized as follows; Expends its kinetic energy on soil particles to detach and splash them, initiating turbulence, which in turn initiates flow and increases the sediment-carrying capacity of fluvial erosion. Causes flow, develops tractive forces, which detaches soil particles and initiates movement. Concentrated overland flow gives rise to gully erosion, while unconcentrated flow gives rise to sheet erosion. Rainfall causes infiltration especially in the loose, uncemented and unconsolidated sands. Infiltration is responsible for every rampant slumping and sliding especially around existing gully sites, with resultant loss to life and property.

Conclusion: Computed results and experience have shown that rainfall is the principal cause of flooding and siltation of streams, rivers, agricultural lands, property and sometimes loss of lives. Flooding often results from poor/absence of drainage systems. Water budget analysis for the area has identified August, September and October as the months during which erosion is at its peak, the anthropogenic and natural causes of gully/soil erosion. Computed data and results obtained are very vital in the design of drainages for flood/erosion control.

Acknowledgement: This paper is dedicated to memory of our beloved colleague, friend and co-author, late Mr. Banlanjo Ernest Wirba..

\section{REFERENCES}

Akudinobi, B.E.B., 1991. The Hydrogeological and geotechnical implications of acid mine drainage problems in Enugu coalmines of Nigeria. Unpublished Ph.D Thesis. Dept.of Geological Sciences, Nnamdi Azikiwe University, Awka.

Banlanjo, E.W., 1994. The Geology of Obinofia Ndiuno and Environs in Ezeagu Local Government Area of Anambra State. Unpublished B.Sc. Thesis. Dept of Geological Sciences,Nnamdi Azikiwe University, Awka.

Egboka, B.C.E., 1994. The Raging War: Erosion, Gullies and Landslides Ravage Anambra State. God's Time Printing \& Publishing Coy., Awka.

Egboka, B.C.E. and Okpoko, E.I., 1984. Gully erosion in the Agulu Nanka region of Anambra State Nigeria. In: Challenges in African Hydrology:335-347. IAHS Publ. no. 144.

Egboka, B.C.E. and Okpoko, E.I., 1988. Hydrogeology of Awka and Njikoka Local Government Areas of Anambra State, Nigeria: A case study of a developing economy. Journal of Hydrology. I.. 45-55.

Freeze, R.A. and Cherry, J.A. 1979. Groundwater: Prentice-Hall Inc., Englewood Cliffs, N.J.

Neyer, A.P. 1915. Computing runoff from rainfall and other physical data. Trans. Am. Soc. Civ. Engrs 79: 1056-1155.

Ofomah, J.C. 1987. Patterns of gully erosion origin and development in Anaocha Local Government Area and Environs, Anambra State, Nigeria. Unpublished M.Sc. Thesis. Dept of Geological Sciences, Nnamdi Azikiwe University, Awka.

Todd, D.K. 1980. Groundwater Hydrology. John Wiley and Sons. Inc., New York 35P. 